\title{
ДОСЯГНЕННЯ, ПРОБЛЕМИ ТА ПЕРСПЕКТИВИ РОЗВИТКУ ДЕРЖАВНОГО ЗАКЛАДУ “ЛУГАНСБКИЙ ДЕРЖАВНИЙ МЕДИЧНИЙ УНІВЕРСИТЕТ”
}

\author{
I. В. Іоффе, С. М. Смірнов \\ ДЗ “Луганський державний медичний університет”
}

\section{ACHIEVEMENTS, PROBLEMS AND PROSPECTS OF DEVELOPMENT STATE OF ESTABLISHMENT “LUGANSK STATE MEDICAL UNIVERSITY”}

\author{
I. V. Ioffe, S. M. Smirnov
}

\section{SE “Lugansk State Medical University”}

\begin{abstract}
У статті представлено досягнення, проблеми та перспективи розвитку ДЗ “Луганський державний медичний університет”. Надана інформація про історію, про видатних діячів університету. Наведена інформація про шлях становлення університету за новим місцем розташування в зв’язку з переміщенням із зони антитерористичної операції.
\end{abstract}

The article presents the achievements, problems and prospects of State establishment "Lugansk State Medical University". Information about the history, prominent figures of the University, information about the way of formation of the University at a new location in connection with the movement of the zone of the antiterrorist operation is presented.

Вступ. У 2016 р. ДЗ “Луганський державний медичний університет” виповнюється шістдесят років. В пам'яті залишається славетна історія становлення медичного інституту, у сьогоденні бачиться активний розвиток сучасного європейського навчального закладу.

Основна частина. 6 травня 1956 р. наказом уряду України в місті Луганськ був заснований другий у Донбасі медичний навчальний заклад. 1956-1967 рр. характеризуються становленням навчального закладу, організацією кафедр і формуванням матеріально-технічної бази інституту. У подальші роки відбувається динамічний розвиток ВНЗ: побудовані власні навчальні корпуси та гуртожитки; організовані нові кафедри: медичної фізики з обчислювальною технікою, інформатикою та кібернетикою; клінічної імунології й алергології та генетики; поліклінічної терапії; відкрито підготовче відділення (1973); створені факультет післядипломної освіти (1979), факультет для підготовки іноземних студентів (1983), педіатричний факультет (1983); відкритий на базі інституту один з перших в Україні медико-біологічний ліцей-інтернат для сільської молоді (1993).

\footnotetext{
(c) I. В. Іоффе, С. М. Смірнов
}

Згідно з Постановою Кабінету Міністрів України від 29 серпня 1994 р. № 592 на базі Луганського медичного інституту був створений Луганський державний медичний університет. У 1995 р. університет був атестований за вищим IV рівнем акредитації. У наступні роки продовжується активний розвиток Д3 “Луганський державний медичний університет”: відкриваються нові факультети й кафедри, укріплюється матеріально-технічна база, розширюється ліцензійний обсяг підготовки, зростає рівень професорсько-викладацького складу, удосконалюються методики та технології викладання, проводяться сучасні фундаментальні та прикладні наукові дослідження, відбувається інтенсифікація лікувальної роботи.

Зокрема, 1997-2014 рр. відзначені значним розширенням матеріально-технічної бази та низкою інших досягнень: закінчено будівництво блоку навчального корпусу, в якому розміщені кафедри анатомії людини, медичної біології, гістології, цитології та ембріології, нормальної фізіології (1997); завершено будівництво аудиторного блоку навчального корпусу (1998); організовані фармацевтичний і стоматологічний факультети, факультет медичних сестер-бакалаврів із вищою 
освітою з подовженим навчальним днем (вечірній) (1998).

Лауреатами Державної премії України в галузі науки і техніки за розробку і впровадження медичної системи життєзабезпечення постраждалих при техногенних аваріях і катастрофах стала група вчених на чолі із заслуженим діячем науки і техніки України, доктором медичних наук, професором Геннадієм Олександровичем Можаєвим (2000); побудована університетська медична бібліотека “Палац книги” (2000); розпочала роботу новозбудована “Аптека-студія” (2001); відкриті обладнана сучасним устаткуванням університетська стоматологічна клініка та університетський стадіон (2003); придбаний санаторій-профілакторій та закладений парк університетського містечка (2003); розпочав роботу Центр сімейної медицини (2004); відкриті тенісні корти та спортивні майданчики (2004).

Весь цей час в університеті плідно працювали фундаментальні та клінічні наукові школи за сучасними напрямками медицини, які провадили актуальні дослідження з урахуванням екології Донбасу та стану здоров’я населення Луганської області.

Наукова школа анатомів і морфологів професора, д-ра мед. наук, заслуженого діяча науки і техніки України, лауреата Державної премії України Володимира Георгійовича Ковешнікова. Під керівництвом професора В. Г. Ковешнікова виконані й захищені 19 докторських та 53 кандидатські дисертації.

Наукова школа біохіміків професора, д-ра мед. наук, заслуженого діяча науки і техніки України Ірини Олександрівни Комаревцевої. Під керівництвом професора I. О. Комаревцевої виконані й захищені 5 докторських дисертацій та 21 кандидатська дисертація.

Наукова школа фармакологів професора, д-ра мед. наук, заслуженого діяча науки і техніки України Віктора Дмитровича Лук’янчука. Під керівництвом професора В. Д. Лук’янчука виконані й захищені 2 докторські дисертації та 27 кандидатських дисертацій.

Наукова школа мікробіологів професора, д-ра мед. наук, заслуженого діяча науки і техніки України Ігоря Славовича Гайдаша. Під керівництвом професора I. С. Гайдаша виконані й захищені 3 докторські дисертації та 29 кандидатських дисертацій.

Наукова школа патофізіологів професора, д-ра мед. наук, заслуженого діяча науки і техніки України Ніли
Казимирівни Казимирко. Під керівництвом професора Н. К. Казимирко виконані й захищені 3 докторські дисертації та 21 кандидатська дисертація.

Наукова школа інфекціоністів і терапевтів професора, д-ра мед. наук, заслуженого діяча науки і техніки України Валерія Митрофановича Фролова. Під керівництвом професора В. М. Фролова виконані й захищені 26 докторських та 130 кандидатських дисертацій.

Наукова школа анестезіологів і реаніматологів професора, д-ра мед. наук, заслуженого діяча науки і техніки України, лауреата Державної премії України Геннадія Олександровича Можаєва. Під керівництвом професора Г. О. Можаєва виконані й захищені 3 докторські дисертації та 24 кандидатські дисертації.

Наукова школа хірургів професора, д-ра мед. наук Олександра Олександровича Ольшанецького. Під керівництвом професора О. О. Ольшанецького виконані й захищені 2 докторські дисертації та 24 кандидатські дисертації.

Наукова школа хірургів професора, д-ра мед. наук, заслуженого лікаря України Ігоря Володимировича Іоффе. Під керівництвом професора I. В. Іоффе виконані й захищені 1 докторська дисертація та 15 кандидатських дисертацій.

Наукова школа терапевтів професора, д-ра мед. наук Володимира Ігнатовича Путінцева. Під керівництвом професора В. І. Путінцева виконані й захищені 1 докторська дисертація та 20 кандидатських дисертацій.

За шістдесят років співробітниками університету захищено більше 150 докторських та більше 700 кандидатських дисертацій. Це дозволило університету зайняти одне з провідних місць серед медичних закладів України, оскільки показник викладачів із науковими ступенями становить більше $80 \%$.

У 2014 р. у Д3 “Луганський державний медичний університет” працювали чотири спеціалізовані вчені ради:

1. Д 29.600.01 з розгляду та проведення захистів дисертацій на здобуття наукового ступеня доктора медичних наук за спеціальностями 14.01.02 “Внутрішні хвороби”, 14.01.38 - “Загальна практика - сімейна медицина” (наказ МОНмолодьспорту України від 29.11.2011 р. № 1380, термін повноважень - 29.11.2011 - 29.11.2013);

2. Д 29.600.02 з розгляду та проведення захистів дисертацій на здобуття наукового ступеня доктора 
наук за спеціальністю 14.03.04 - “Патологічна фізіологія” (біологічні, медичні науки) (наказ МОН молодьспорту України від 26.09.2012 р. № 1049, термін повноважень - 26.09.2012 - 26.09.2014);

3. Д 29.600.03 з розгляду та проведення захистів дисертацій на здобуття наукового ступеня доктора наук за спеціальністю 14.01.32 - "Медична біохімія” (біологічні, медичні науки) (наказ МОНмолодьспорту України від 17.02.2012 р. № 188, термін повноважень - 17.02.2012 - 17.02.2014);

4. Д 29.600.04 з розгляду та проведення захистів дисертацій на здобуття наукового ступеня доктора наук за спеціальністю 14.03.01 - “Нормальна анатомія” (біологічні, медичні науки) (наказ ВАК України від 31.05.2011 р. № 469, термін повноважень - 01.06.2011 - 01.06.2013).

У 2014 р. Д3 “Луганський державний медичний університет” здійснював випуск дев’яти науковопрактичних журналів: “Український медичний альманах”, “Український морфологічний альманах”, “Український журнал клінічної та лабораторної медицини”, “Український журнал екстремальної медицини імені Г. О. Можаєва”, “Загальна патологія та патологічна фізіологія”, “Проблеми екологічної та медичної генетики і клінічної імунології”, “Перспективи медицини та біологї”, “Актуальні проблеми акушерства і гінекології, клінічної імунології та медичної генетики”, “Хірургія Донбасу”.

В останні десять років навчальний процес в університеті забезпечували 52 кафедри шести факультетів: медичного за спеціальностями “Лікувальна справа” і “Педіатрія”, стоматологічного, фармацевтичного, іноземних громадян та післядипломної освіти.

У 2014 р. в Д3 “Луганський державний медичний університет” працювали майже 700 викладачів, у тому числі: докторів наук, професорів - 88, кандидатів наук, доцентів - 493. Кількість осіб, які навчалися в державному закладі, на 2014 р. перевищувала 5500.

За роки існування університетом підготовлено понад 20000 лікарів, у тому числі майже 19 тисяч лікарів-лікувальників, близько 1500 лікарівпедіатрів, більше 300 медсестер-бакалаврів, 600 провізорів та 200 лікарів-стоматологів, також близько 19 тисяч лікарів-інтернів та лікарівкурсантів, а також більше 1000 лікарів для 52 іноземних країн.

За період з 1956 по 2016 р. ректорами університету були: Іван Данилович Ващенко, Євген Гнатович
Пальчевський, Федір Дмитрович Повеліця, Донат Григорович Корчиков, Ірина Йосипівна Чайковська, Анатолій Миколайович Фаддєєв, Володимир Ковешніков, Валерій Костянтинович Івченко. На сучасному етапі діяльністю університету керує Ігор Володимирович Іоффе.

У зв’язку з проведенням антитерористичної операції в Луганській та Донецькій областях на виконання пункту 3 Постанови Кабінету Міністрів України від 07 листопада 2014 р. № 595 “Деякі питання фінансування бюджетних установ, здійснення соціальних виплат населенню та надання фінансової підтримки окремим підприємствам і організаціям Донецької та Луганської областей” та згідно з наказом МОЗ України від 21.11.2014 р. № 875 “Про організацію діяльності Луганського державного медичного університету” університет був переведений за новою юридичною адресою у м. Рубіжне.

Ректоратом та колективом університету було вжито всіх необхідних заходів щодо організації навчального процесу та подальшого розвитку вищого навчального закладу. У 2015 р. університет здійснив перший випуск спеціалістів та перший набір на навчання за новим місцем розташування. Відновлення повноцінного навчального процесу стало можливим завдяки допомозі з боку Міністерства охорони здоров'я України, медичних та фармацевтичного вищих навчальних закладів України, співпраці з органами місцевої влади та суспільними організаціями. На сьогодні плідно працюють всі структурні підрозділи ДЗ “Луганський державний медичний університет” у м. Рубіжне Луганської області. В університеті здійснюють свою діяльність шість факультетів: лікувальна справа, педіатричний, стоматологічний, фармацевтичний, післядипломної підготовки, іноземних студентів. Навчальний процес забезпечують 30 кафедр. Клінічні бази університету розташовані в кращих обласних та міських лікувально-профілактичних закладах міст Рубіжне, Лисичанськ, Кремінна, Сєверодонецьк. Теоретичні кафедри розташовані в орендованих приміщеннях.

Професорсько-викладацький склад університету становить 113 осіб, з них докторів наук, професорів - 20, кандидатів наук, доцентів - 42. На умовах погодинної оплати в університеті працюють 3 доктори наук, професори. В університеті навчаються більше 500 студентів, 90 інтернів, 300 курсантів. 
32015 р. за новим місцем розташування у дз “Луганський державний медичний університет” працюють дві спеціалізовані вчені ради:

1. Д 29.600.02 з розгляду та проведення захистів дисертацій на здобуття наукового ступеня доктора (кандидата) наук за спеціальностями 14.01.03“Хірургія" та 14.03.04 - "Патологічна фізіологія" (медичні та біологічні науки) (наказ МОН України від 12.05.2015 р. № 528, наказ МОН України від 13.07.2015 р. № 747 (розширення профілю), термін повноважень - 12.05.2015 - 12.05.2017);

2. Д 29.600.03 з розгляду та проведення захистів дисертацій на здобуття наукового ступеня доктора (кандидата) наук за спеціальністю 14.01.32 - “Медична біохімія” (біологічні, медичні науки) (наказ МОН України від 06.03.2015 р. № 261, термін повноважень - 06.03.2015 - 06.03.2017).

Співробітники клінічних кафедр університету беруть активну участь у наданні медичної допомоги населенню Луганської області. За минулий рік ними було надано 9638 консультацій, проведено 3669 оперативних втручань. Значна частина цих консультацій та оперативних втручань здійснювалась у безпосередній близькості від лінії розмежування.

Основними проблемами Дз “Луганський державний медичний університет” є відсутність роз- виненої матеріальної бази, власних приміщень для здійснення навчального процесу та відсутність гуртожитків; недостатня кількість друкованої навчальної літератури; недостатня кількість технічного обладнання, необхідного для навчального процесу; брак обладнання для проведення наукових досліджень; відсутність житла для викладачів; розташування університету в безпосередній близькості до лінії розташування.

Висновки. Перспективи розвитку Д3 “Луганський державний медичний університет” залежать від розвитку політичної ситуації, від здійснення заходів щодо реалізації програми розвитку переміщених навчальних закладів, від позиції Міністерства охорони здоров’я України та Міністерства освіти і науки України.

Колектив університету зі своєї сторони робить все необхідне для укріплення та розвитку навчального закладу. Пріоритетними напрямками розвитку Д3 “Луганський державний медичний університет” є: відновлення матеріально-технічної бази; підвищення рівня професорсько-викладацького складу за рахунок залучення фахівців та підготовки власних висококваліфікованих кадрів; розширення контингенту осіб, які навчаються в ДЗ “ЛДМУ”.

Отримано 01.04.16 